\title{
The Role of Local Government on Rural Tourism Development: Case Study of Desa Wisata Pujonkidul, Indonesia
}

\author{
Firdaus $^{1,2^{*}}$, Sudarsono Hardjosoekarto ${ }^{2}$, Robert M.Z. Lawang ${ }^{2}$ \\ ${ }^{1}$ Sociology Education Department, Universitas PGRI Sumatera Barat, Padang 25137, Indonesia \\ ${ }^{2}$ Sociology Department, University of Indonesia, Depok 16424, Indonesia \\ Corresponding Author Email: firdaus.lasigo@gmail.com
}

https://doi.org/10.18280/ijsdp.160710

Received: 19 June 2021

Accepted: 16 November 2021

\section{Keywords:}

rural tourism, rural tourism development, village government, Desa Wisata Pujonkidul

\begin{abstract}
Tourism has contributed significantly to economic growth, and the government is the leading actor in the tourism development process. This article aims to discuss the role of village government in rural tourism development. The research was conducted qualitatively with a case study in Pujonkidul, a tourist village that is growing and developing into a rural tourism destination rapidly in Indonesia. The research data were collected through a series of in-depth interviews with village governments and main actors in the rural tourism development process. Observation and study of document also carried on during the process of collecting data the village. The result of study show that the local government is able to carry out all government functions in tourism development (coordination, planning, regulation and legislation, entrepreneurship, stimulus and promotion, social tourism role and boarder role of interest protection). This study also found a new function of government in tourism development which is the main finding of this study, namely institutional development. Therefore, the authors argue that the village government can conduct rural tourism development locally and effectively with its functions and authorities. This finding of study can be adopted and developed in the other villages in the process of rural tourism development. The limitation of this study has ignored the discussion of villagers' participation in the rural tourism development process that is the essential form of rural development issues. This limitation is an important topic for future research.
\end{abstract}

\section{INTRODUCTION}

Tourism has developed as a viable alternative and source of income in rural areas during the last few decades [1-3]. The social and economic benefits of tourism for rural areas are essential issues in the literature review that observed the relationship between tourism development and the rural economy [4]. Although sometimes rural tourism development also triggers conflict [5], the social and economic benefits have encouraged rural tourism development.

There are many studies on the important role of the government in the development process of the tourism sector in general [6-8] and rural tourism in particular $[9,10]$. The main findings of previous studies show that in the tourism development process, the government is the leading actor in the development of the tourism sector at various levels, even though the government sometimes turns out to be an obstacle in the tourism development process [11-13]. However, there are limited studies of the village governments' role in rural tourism development. Previous studies tend to discuss the role of government at the national, provincial, and district levels [6, $8,9,14]$. Wilson et al. [15] stated that rural tourism development could be developed locally without outside actors through community participation and supported by the village government.

In particular, the limited studies of government and village government also take place in Indonesia [16-18]. Several rural tourism studies focus on tourism potencies, strategies and policies [19-21] and tourism impact on the social and economic life of rural communities in providing employment and new economic sources [22-24]. Meanwhile, rural tourisms have grown by $75.08 \%$ in Indonesia in 2014-2018. The existing rural tourism in Indonesia has grown from 1,302 villages (2014) to 1,734 villages in 2018 [25]. This figure is predicted to develop along with the growth trend of the tourism sector in Indonesia of $6.8 \%$ with a total of 1,323 million foreign tourists in 2017 [26] and a program to accelerate tourism infrastructure and facilities to increase the capacity of the tourism sector in Indonesia [13].

To fill in the gap of the study of rural tourism development in Indonesia and the role of village governments in rural tourism development, this study aims to discuss the role of village governments in rural tourism development. Desa wisata Pujonkidul is used as a case for research purposes. Pujonkidul tourist village is one of the tourist villages proliferating as a rural tourism destination in Indonesia. Initiated in 2016 through the construction of Café Sawah, the tourism sector has been able to employ 600 workers and generate 1.9 billion Rupiah of Village Original Income/Pendapatan Asli Desa (PADes) in 2019. All tourism village development processes are carried out entirely by the village government through BUMDes and involve the village community. This achievement makes Pujonkidul village one of the ten best villages in Indonesia using village funds in 2018 . 
This article is significant in the framework of the regional autonomy system in Indonesia and the village government system as stated in Regulation No. 6/2014 about the village. The autonomy system and the village government system provide a wider area for the village to manage and develop the potential for the welfare of the residents. This contribution is widely important for countries on the rural community bases in the development process, such as China [27], Africa [28].

\section{LITERATURE REVIEW}

\subsection{Rural tourism}

Historically, rural tourism has developed since the industrial revolution as "mudik" or homecoming activity for city residents who come from the rural area to take the holidays. These activities started to develop rapidly since the $70 \mathrm{~s}$ in all developed countries worldwide, and they played a crucial role in rural areas' social and economic development [29]. The early studies on rural tourism focused on local and regional development, consumer preferences, and technology [30]. The complexity of tourism as a service industry provides new jobs and various entrepreneurial activities [31] requires studies that are not limited to the study's initial focus. Multiple perspectives and approaches to rural tourism studies keep on developing in various disciplines of knowledge. Thus, the concept of rural tourism is diverse and lacks consensus [32].

Bernard Lane mentions two famous myths in the understanding of rural tourism. First, there is the myth about agriculture-based rural tourism or agro-tourism. Second, the myth of diversification into tourism will save farming communities. Both of these myths are demystified because the relationship between agriculture, forestry, and tourism is complex. Therefore, Lane defines rural tourism as tourism in the countryside [33]. Lane, Ghaderi, and Henderson [34] define rural tourism as tourism in rural areas. This concept is inclusive. Therefore, Lane further says that rural tourism is a complex multi-face activity. It is not based solely on agriculture. Rural tourism includes all activities in a rural environment capable of providing peace, tranquility, and relaxation in a rural setting. The concept of rural tourism by Lane has been widely cited in rural tourism studies. This is mainly due to its more comprehensive coverage as almost all activities in the countryside aim for peace, tranquility, and relaxation through rural activities for tourists. Thus, rural tourism is the antithesis of mass tourism as a unique place to get away from city life and standard and impersonal services [35].

As the antithesis of mass tourism, most rural tourism definition refers to tourism activities in rural areas or the countryside [36-39]. Specifically, Ezeuduji states that rural tourism involves visiting rural areas to enjoy the rustic natural atmosphere and participate in the way of life of rural communities [28]. Rural tourism has no competition because no other tourism practice can provide the same experience as the uniqueness and authenticity of rural tourism [35], particularly those related to the natural atmosphere and way of life in the countryside.

Although there are many different definitions of rural tourism given by experts, there is one common thread that unites the various definitions. Experts agree that rural tourism refers to tourism activities carried out in rural areas which in various literatures are called rural areas or countryside. As a study on the rural tourism development issues, in this study rural tourism refers to all tourism activities in rural areas with both natural and artificial objects that specially made as tourist destination.

\subsection{Government role in rural tourism development}

Government has played an important role in the tourism planning and development process. Economic factors are the main factor in encouraging governments' roles in the tourism sector aside from residents' expectations of improving the local economy, better employment opportunities, improved infrastructure, and investment opportunities [40]. Government engagement has also garnered widespread support due to its mandate to protect the population's interests, its perceived impartiality toward commercial interests, its legislative authority to effect change, and its independence from shortterm financial aims, as private firms are [12]. This is related to the view of Devine and Devine that state if tourism planning, promotion, and management were left entirely to the private sector, this could result in the unbalanced development of infrastructure and market expansion, with the risk of growing congestion and increased pressure on environmental resources [41].

Numerous studies show that government involvement in tourism planning and development has contributed positively to the tourism sector in the development of the social and economic sectors $[11,12,14,42]$. The role of government in tourism development starts from resource investment, planning policies to tourism promotion [7]. In general, the government created the economic climate. It provided various rules in which the tourism industry works and has also played an important role in tourism planning, management, and promotion [9]. Hall [43] also lists eight general functions of government related to tourism, namely coordination, planning, legislation and regulation, entrepreneur, stimulation, promotion, social tourism role, and the broader role of interest protection [43].

Furthermore, Hall explained that the role of coordination is the government's efforts in coordinating actors (individuals and groups) of various interests in the tourism sector. The role of planning is the responsibility of decisions making for future actions in order to achieve the aims of tourism development. It includes various aspects such as infrastructure, resources, institutions, and so on. The role of regulation and legislation is the inherent authority of the government to determine rules in tourism. The government can carry out the part of entrepreneurs by owning and operating a tourism business directly owned by the government and companies to support tourism activities. The purpose of stimulation is to energize the process of tourism development. Government attempts to promote tourism demand, including investment, fall under the category of promotion. Mill \& Morrison's promotional involvement [44] was included as part of the stimulatory role. Mill \& Morrison state that government can stimulate tourism through financial incentives, sponsoring research on tourism, and marketing and promotion. The government's role for social tourism includes efforts to expand the benefits of tourism to economically marginalized groups. In protecting broader interests, the government is obliged to protect the wider public interest than the sectorial interests of certain groups.

Government with their authority also has the function of institutional development. Israel state that institutional 
development is refers to the process of improving the ability of institutions to make effective use of human and financial resources available (variously defined as) institution building, public sector management, public administration, and so on [45]. Furthermore, Buyck [46] said that Institutional development is the creation or reinforcement of an organization's capacity to generate, allocate, and use human and financial resources effectively to attain development objectives, public or private. It includes the building and strengthening an institution and its reduction, liquidation in the pursuit of institutional, sectoral, or government-wide rationalization of expenditure. Operationally, institutional development is typically aimed at improving and strengthening internal organizational structures; management systems; financial management and planning systems; personnel management, staff development, and training; interinstitutional relationships; institutional structures of subsectors or sectors; legal framework; and government regulations and procedures. In summary, McGill [45] state the institutional development is seen as having an internal concern with its organization and an external problem with its development environment.

\section{METHOD AND RESEARCH SITE}

This research is qualitative with case study approach to utilize a wide space in understanding the role of village government in the rural tourism development process through investigations into various programs and processes [47, 48]. The use of case studies is very relevant to examine the complexity of the system that works in the tourism village development process through investigations of various programs, events, activities, processes, or individual groups. [47]. Pujonkidul in Malang Regency's, Pujon District was chosen as the case study location. It is based on Pujonkidul's designation as the most remarkable national village for rural tourism development in 2018. Pujonkidul is a rural location capable of rapidly changing into a tourism village.

Geographically, Pujonkidul is a highland village in Pujon sub-district of Malang Regency Indonesia (Figure 1). Pujonkidul is a hilly area with an altitude of 1,200 mdpl which is dominated by sloping topography rather than steep. This condition allows the site to be managed by residents who predominantly work in the agricultural sector and dairy farming as agricultural land. Geographically, Pujonkidul is only $\pm 15 \mathrm{~km}$ from the western town of Batu, a tourist town in the province of East Java. Pujonkidul takes 10-15 minutes by car from the tourist town of Batu. Meanwhile, it is only $40 \mathrm{~km}$ away from Abdurrahman Salah Airport or 1.5-2 hours by car.Data was carried out through in-depth interviews with informants of main actors in the development process of Desa Wisata Pujonkidul. In-depth interviews were conducted to represent the subjective world of the interviewees/main actors of tourism village development [49]. Informants consist of the village head, the chairman of the Village Representative, the Director of BUMDes (Village Owned Enterprises) Sejahtera and the head of the Tourism Awareness Group (Pokdarwis). The interview process was carried out in a semi-structured at the village office, at the informants' house, and at the village tourism objects. The informan was selected purposively with the consideration of directly involved in the development process of the Desa Wisata Pujonkidul. They understand the topics of the interview because they involve with the subject. Thus, the data process was also carried out by tracing official village government documents in the Village such as Village Regulations (Perdes), Village Medium Term Development Plans (RPJMDes), BUMDes Report and other relevant documents. To verify and enrich data from interviews and official village documents, observations were made during the data gathering process by visiting all tourist attractions in the village.

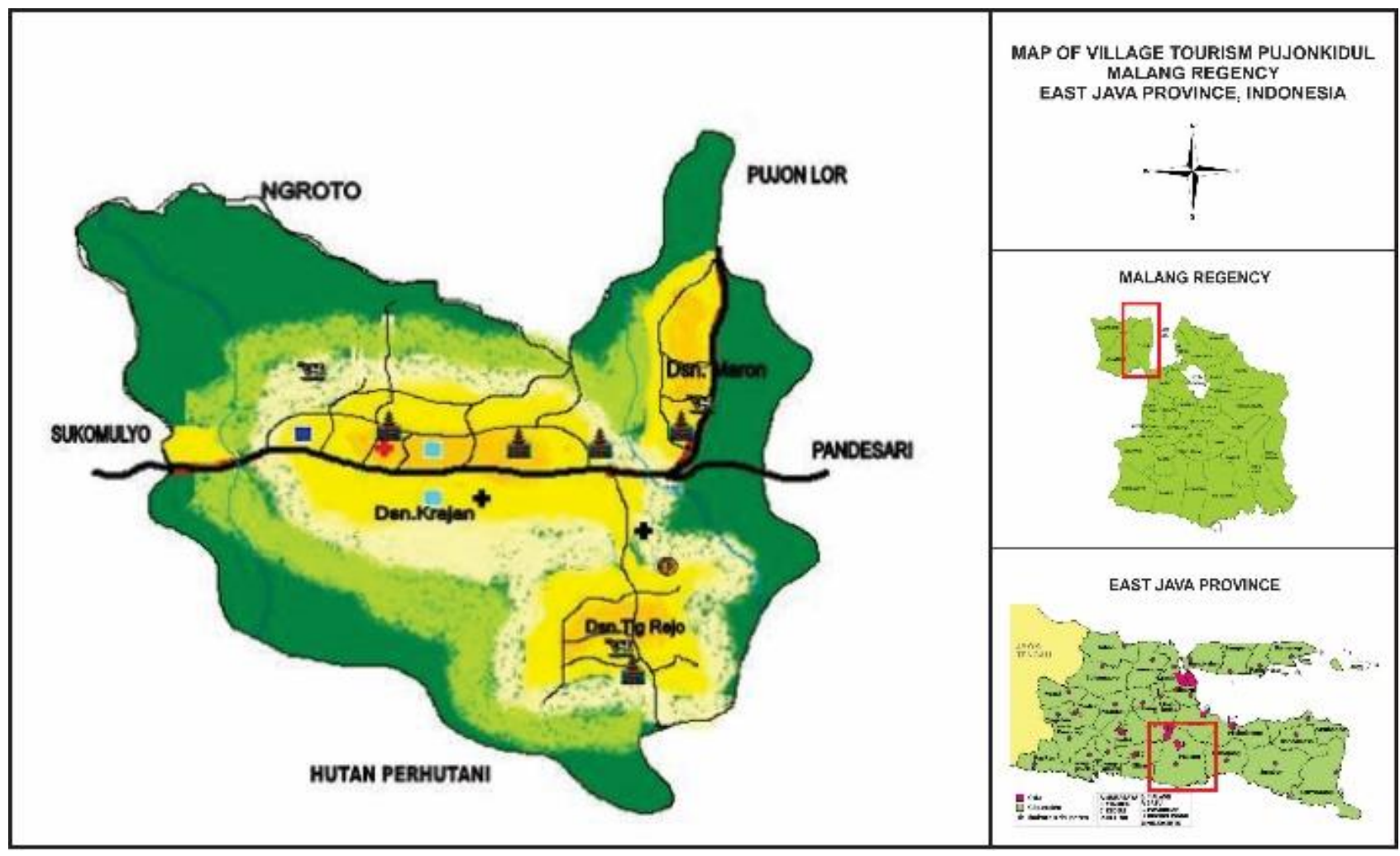

Figure 1. Map of Pujonkidul village 
The average interview lasted for 1-1.5 hours. The recordings of the interviews were transferred to the text for later thematic analysis. Interview themes were then grouped according to research objectives. The process of grouping data has been going on since the semi-structured interviews. The interview transcriptions were also carried out according to the research theme. The results are interpreted and presented in this article descriptively according to the research objective. This process refers to the stages of data reduction/verification, data display, and data interpretation as implied in qualitative research [50].

\section{RESULT AND DISCUSSION}

\subsection{Tourism development of Pujonkidul village}

The idea of rural tourism development at Pujonkidul has been started since 2011. This is the idea of Udi Hartoko on his assessment of the tourism potential in Pujonkidul. Udi analyzed Pujonkidul as a potential tourist attraction as well as other former rural tourism. These potentials are natural (landscape and the cool air of the mountains), cultural (kuda lumping "traditional theater," wayang "puppet shows", and Pencak silat "martial arts") and the daily activities of residents (agro-farming, apple, and citrus plantations, and dairy farming). Based on Udi's meanings, these potentials are significant sources of tourist attraction, especially for the city travelers.

“... I was with my friend to look for a grass and wood. In our break, we talk about the village. "We have a beautiful nature. This village is awesome. If people just go around Batu (a city), maybe they will be bored." (Interviewed Udi, June 18, 2019)

To realize the ideas of rural tourism development at Pujonkidul, Udi decided to run as a candidate for village head in the village head election 2011. After being elected as village head, Udi embodied his idea about Desa Wisata Pujonkidul by his authority. However, his efforts were not accepted by Pujonkidul's society. People are familiar and comfortable with livelihoods in the agricultural sector and dairy cows. They reject the development of tourism at the Pujonkidul village. They think the tourism development will only spend the village budget. The refusal is based on their perception of tourism as the entertainment and shopping center building reflected in the town. Based on this point of view, they considered that it is impossible to build rural tourism.

As village head born and grew up in the village, Udi understands the common view of the community about tourism because of limited awareness of the concept of a rural tourism. Based on this situation, Udi involved several youths in understanding the community about rural tourism by exploring the local potential. Based on the assessment and mapping of the potential, there is an idea of educational tours in packages, namely agricultural education, livestock education, and cultural education. An agricultural education package is designed as a tour to the area of agriculture and farming community. In this package, tourists are involved in gardening activities, rice fields, and picking apples and oranges. Animal husbandry education tour packages are tour to residents' dairy cows. Travelers involved in the maintenance and milking dairy cows. Cultural education tour packages are in the form of wayang or puppet shows, kuda lumping or traditional theater, and pencak silat or local art for tourists. In order to accompany visitors to educational tour packages, an Event Organizer (EO) group from local youths is formed to guide.

The village government has assigned the EO's members to attend various tourism-related training and activities to assist human resources. One of the training is bridge EO to meet with the Department of Tourism and Culture of Malang Regency. Based on the meeting in 2013, the Department of Tourism and Culture advised EO to transform into a Travel Awareness Group (Pokdarwis) to get a formal legal basis as the pioneer of rural tourism development Pujonkidul. Based on these suggestions and assistance from the Tourism Office, EO is transformed into Pokdarwis. Thus, it is well-known as Capung Alas.

In developing the tourism sector in the Pujonkidul, the village government gives authority to Pokdarwis Capung Alas to open, develop, and manage Sumber Pitu tourism object as a mass tourism object. Sumber Pitu tourism object is a natural tourist destination that has seven waterfall points in the exact location. The Sumber Pitu tourism object package is not only limited to a waterfall, but it is also a trail motorbike and hiking attraction to reach a location about $\pm 4 \mathrm{~km}$ from the Telungrejo beside the Perhutani forest area. Management of Sumber Pitu is a cooperation between the Pujonkidul government, Pokdarwis Capung Alas, and Perhutani. In 5 months, Pokdarwis was able to get in an average of 1000 visitors per day on weekends and 500 visitors per day on weekdays.

The collaboration management between Sumber Pitu and Perhutani lasted only eight months since the opening. In June 2015, the village government asked Pokdarwis to stop managing Sumber Pitu and return it to Perhutani due to a deadlock in the cooperation agreement. Pokdarwis was asked to focus on managing and developing educational tour packages. However, for nearly six months managing educational tours, the development of educational tours is not very good. Within a month, the village only received 1-2 packages, sometimes even without tourists. In a quiet atmosphere of visitors, in early 2016, Pokdarwis took the initiative to create Balai Tani Desa building or Local Farmer Convention Hall by CSR of BUMN bank on village-owned land in 2015 as a food court for coffee and selling fried food and snacks (Figure 2a). Two gazebos were built next to the Local Farmer Convention Hall. This place is called Café Sawah to drink coffee while enjoying the nature of the paddy field with a mountain background.

The development of Café Sawah as a new rural tourism object has received wide attention from the public of Pujonkidul and the neighborhood. This café is designed as a good place to take a photo. The set-in mountains and rice fields have attracted many visitors to come into the cafe. This capture is shared through social media (Figure 2b). Visitors have continued to increase in just 2-3 months since Café Sawah was launched. The increasing potential has prompted the village government to allocate a budget for the development of Café Sawah. In 2016, the village government allocated 60 million rupiahs from the Village Revenue and Expenditure Budget (APBDes), and in 2017 another 150 million rupiah was budgeted to stimulate the development of Café Sawah. In order to be able to allocate stimulus funds from the APBDes, Café Sawah was transferred from Pokdarwis to BUMDes by forming a tourism business unit under BUMDes. The chairman of Pokdarwis was appointed as manager of the tourism unit of BUMDes. 


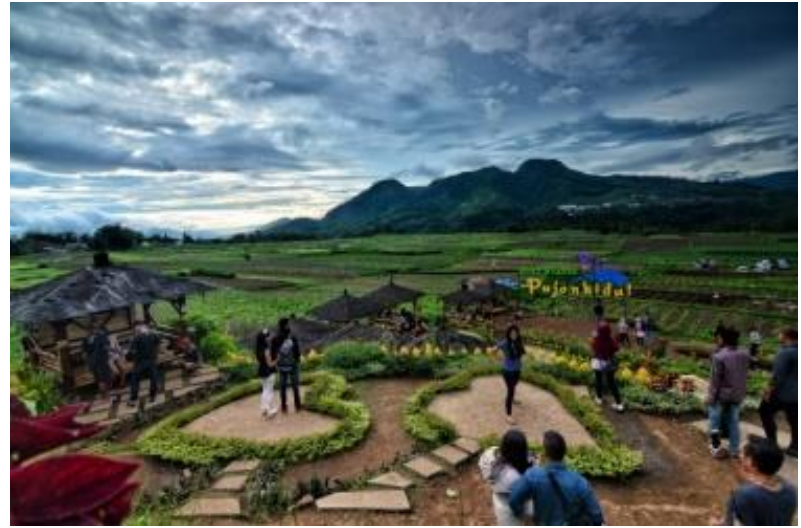

(a)

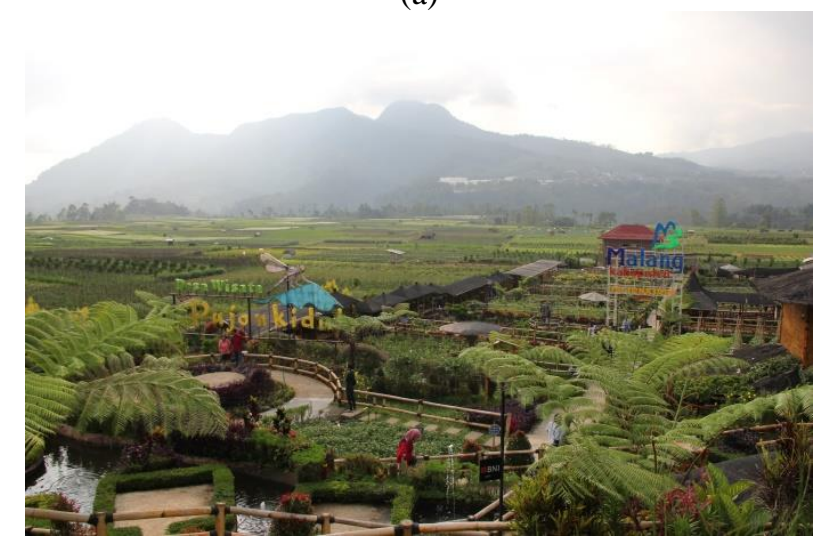

(b)

Figure 2. (a). Cafe Sawah in earlier stage (2016) (Photo by Village Government). (b). Cafe Sawah after developed (2019) (Photo by authors)

The development of Café Sawah as a tourist destination increases along with the construction of new tourist objects around Café Sawah such as the rood 78, Fantasi Land, Petik Strawberi, Mahardika, Manduro, Taman Budaya, and Lumintu, which offers a variety of tourist attractions. The local people independently build some new places around Café Sawah. All of the area can be seen in Figure 3.

New destinations are around Café Sawah, but they are also built by groups of local people at different locations in the village. However, the management of the Café Sawah area is under the management of BUMDes Sumber Sejahtera through the tourism unit. The growth of new objects around Sawah Café is supported by rides and attractions for tourists of Pujionkidul. The diversity of destinations and attractions boosts the number of visitors.

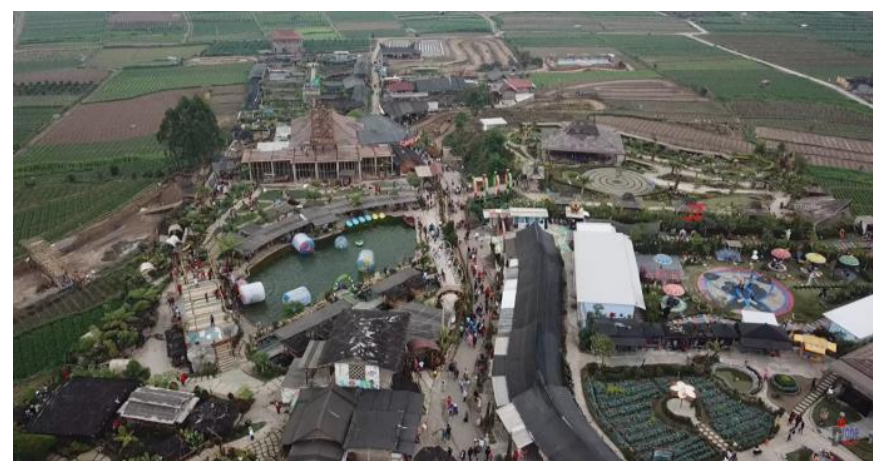

(Photo captured from Youtube of Drone Jowo)

Figure 3. Area of Cafe Sawah

\subsection{The role of village governments in the development of} rural tourism

The village government of Pujonkidul through BUMDes Sumber Sejahtera is the main actor in the development process of Desa Wisata Pujonkidul through BUMDes Sumber Sejahtera. In its establishment of 2014, business units of BUMD had two business units, and it grew to 8 business units in 2019. Three of these business units focus on managing the tourism sector, namely the Café Sawah unit, the parking unit, and The Live In unit. Each unit works separately, but it is integrated for the development of the tourism sector in Pujonkidul. As the leading actor in the development of the Desa Wisata Pujonkidul, the village government has played an essential role of the government functions in the tourism development process.

\subsubsection{Coordination}

In the system of governance, coordination is a political activity on formal relationship between the institutionalized network of organizations, individuals, and interests [43]. In the rural tourism development process of Pujonkidul, the village government has managed three elements to jointly take part in rural the development process of rural tourism. In the initial development process, the village government involved several individuals and created an EO which later transformed into Pokdarwis. The village government also connects Pokdarwis with Perhutani in the opening of the Sumber Pitu. The village government is linked to Perhutani, but the village government has also associated Pokdarwis with automotive sports organizations opening and launching the Sumber Pitu.

In the earlier process of Café Sawah, the village government also coordinated Pokdarwis with other institutions (BUMDes Sumber Sejahtera) as a semi-autonomous institution at the village level. Through good political communication skills from the village government, Pokdarwis as the initiator of the development of the Café Sawah tourist attraction, even fully supported the incorporation of Café Sawah into the BUMDes business unit. Good political negotiations were carried out by determining the Pokdarwis's chairman as the manager of the tourism unit at the BUMDes Sumber Sejahtera.

In addition, the village government has also coordinated the actors of rural tourism with the government at the village level and other stakeholders in the tourism sector. The village government connects EO and Pokdarwis for the benefit of fostering and increasing the capacity of members. Through tourism stakeholders, the village government collaborates with tour leaders and hotels in the city of Batu in the marketing of education tourism packets. The relation of this cooperation is conducted by utilizing the network of the village head. Recently, the village government also coordinated with all stakeholders in Pujonkidul to arrange the regulation of rural tourism in Pujonkidul.

\subsubsection{Planning}

The village government of Pujonkidul has never planned tourism development at Desa Pujonkidul before 2011. However, the vision of the village head for the 2011-2017 is Pujonkidul as a rural tourism under village government accommodation as of village government is an important part of planning rural tourism development in Pujonkidul. In order to support the rural tourism development plan, the village government has collaborated with the Department of Regional and City Planning, Faculty of Engineering, Universitas 
Brawijaya, in mapping the potential of tourism in Pujonkidul. The collaboration was carried out in 2015 after Pujonkidul was designated as a tourism village in 2014. The report document on the development of the village's potential is the village government's blueprint to plan the development of village and tourism sector.

The document report on the development of village potentials conducted by Brawijaya University recommends the development of a tourism village with a zoning or cluster system. For the development of the tourism sector, 3 clusters are recommended, namely the educational tour cluster in Krajan, home industry tourism in Maron, and tourist adventure in Telungrejo. Then, the clustering is the direction for the development of the Desa Wisata Pujonkidul. However, in its implementation, clustering is undergoing changes along with social and institutional dynamics at the local level. Desa Wisata Pujonkidul development policy oriented Krajan as a central destination for Café Sawah and Homestay, Telungrejo as a cultural tourism destination, and Maron as an educational and home industry tourism destination.

\subsubsection{Regulation and legislation}

One of the government authorities that can affect the tourism sector both directly and indirectly is regulation through legislative and regulatory authorities [43]. The Pujonkidul government has a legislative responsibility to arrange the management of local tourism through Village Regulation (Perdes) No. 6 of 2017. This Perdes regulates the development of the tourism sector in Pujonkidul explicitly. The village government can only carry it out through BUMDes, Pujonkidul communities, and or collaboration between village government and communities. In addition, this Perdes also regulates that external investors are not allowed to invest in the tourism development process in Pujonkidul.

Tourism governance arrangements in Pujonkidul that limit rural tourism development actors aim to protect villages and villagers from outside investment. It has the potential to limit residents' space and benefits from the tourism sector. This goal is based on the direction of the development of the Desa Wisata Pujonkidul, which the local people must fully manage. Local people must be positioned as actors, managers and owners of rural tourism.

\subsubsection{Entrepreneur}

In order to carry out the entrepreneurial function, the Pujonkidul village government has succeeded in building tourism as a village-owned business. Even though at the initiation stage of the tourism development plan was rejected, the village government was able to slowly convince villagers to use village funds to build Café Sawah on the village assets land, which is now a village tourism icon. As a village-owned business, Café Sawah is managed by BUMDes Sumber Sejahtera through a particular unit, namely the Café sawah unit. BUMDes also manages parking and ticket through the parking unit and educational tour and live-in packages through the live-in unit. As a result, in 2018 the Sawah café was able to generate Original Local Income (PADes) of 412 million rupiahs, up $253 \%$ from the 2017 PADes of 162.5 million rupiahs.

Apart from managing Café Sawah, parking, educational tour packages, and Live In, BUMDes also manages other village-owned businesses to support tourism businesses. The business is mainly trading logistical materials for the culinary needs of Café Sawah and other tourist objects that provide culinary services. Food logistics materials are not only used to fulfill the needs of tourism services, but also for the needs of the wider community.

\subsubsection{Stimulation and promotion}

The Pujonkidul government has provided a stimulus in the rural tourism development process. Mill \& Morrison [44] mentioned stimulation of the tourism development process of the government that can provide financial incentives, sponsor for tourism development research, marketing, and promotion. The local government gave financial incentives in 2016 and 2017 to stimulate the construction of Café Sawah. Financial incentives are provided by allocating village funds through APBDes for the development of Café Sawah. In addition, the village government has also allocated village funds for infrastructure development to support the development of rural tourism.

The village government carried out research on developing tourism potential in collaboration with Universitas Brawijaya. This activity was carried out in 2015. One year after Pujonkidul was designated as rural tourism by the Department of Tourism and Culture of Malang Regency. This is a comprehensive research report for Desa Wisata Pujonkidul in integrated. It is a blueprint of the village government to plan development. The village government takes tour leaders and hotel management in marketing educational tourism packages for marketing and promotion. In developing Sumber Pitu and Café Sawah, the village government assists with marketing and promotion by connecting Pokdarwis with various tourism actors at the district and provincial levels. Thus, for promotional purposes, the village government has also branding the village as a Rural Tourism with the Refreshing and Fun Education brand.

\subsubsection{Social tourism role}

The village government realizes that the majority of village human resources have low education $(58 \%$ of the population education is elementary education). Then, the village government regulates that only Pujonkidul villagers can work in the village tourism sector and does not allow residents from outside the village to be employees of Café Sawah and other village tourism objects. This arrangement aims to close competition between workers from within the village and workers from outside the village. With the low level of education of villagers, it is feared that villagers will not be able to compete with other workers from outside.

\subsubsection{Broader role of interest protection}

In order to carry out the role of protection for broader interests, the design of the Pujonkidul tourism development concept takes the community as the owner, actor and manager. Thus, the community is not only the audience, but the main actor. To ensure that villagers are the main actors in the tourism business, the village government has issued a policy that the village government can only carry out tourism development in Pujonkidul through BUMDes, village residents, and village government cooperation with the village residents. This policy is regulated in village Regulation (Perdes) No. 6 of 2017 about Tourism Governance. This regulation also prohibits outsiders or bringing in outside investors from building tourist objects in Pujonkidul village. Through the existence of regulations at the village level, the tourism business in Pujonkidul will only belong to the villagers and the village government. 


\subsubsection{Institutional development}

Institutional development on organizations is the main focus of neo-institutionalism in sociology which refers to organizations development [51]. In the process of Pujonkidul as rural tourism, the village government has encouraged the formation of new institutions and developed existing ones. The village government formed a new institution by encouraging some youth to form EO as educational tour operators. It not only encourages the establishment of EO, but the village government also facilitates the capacity of EO members through various training and tourism activities. Through these activities, EO was transformed to Pokdarwis as an organization that had never existed before at the village level.

In addition to encouraging the establishment of new institutions, the village government also encourages existing institutions, namely BUMDes Sumber Sejahtera. BUMDes, which was initially formed only to manage clean water and waste, developed its role and function to participate in managing the rural tourism sector. At the early stage, only one BUMDes unit was involved in tourism management with Café Sawah and Live In package responsibility. However, along with the development of the tourist sector, the tourism unit is divided into 3 units, namely the Café Sawah unit which manages Café Sawah, the parking unit that manages parking and ticketing in the tourist area, and the Live-In unit which focuses on managing educational and Live-In tour packages. This effort shows the village government success in developing the institutional aspects at the village level.

\section{DISCUSSION}

This research focuses on the role of village government in the development of rural tourism. The government of Pujonkidul, through its roles, functions, and authority successes in developing rural tourism in stages, starting from sprouting, start-up, growth, and development stages [27]. Each stage is defined by initiating activities and fostering multistakeholder understanding, opening and developing objects (education tourism, Sumber Pitu, and Café Sawah), developing new destinations, and expanding existing objects to all corners of the village in order to make the entire village a tourist attraction. In the last stage (development), the village government has started to prepare infrastructures and supporting facilities, for example, streets, traditional homes (in Telungrejo), and education and home industry (in Maron).

As the primary actor in rural tourism development, the Pujonkidul government has fulfilled all of Michael Hall's [43] stated government functions in tourism, including coordination, planning, regulation, and legislation, entrepreneur, stimulus, and promotion, social tourism role, and border role of interest protection. In addition, the Pujonkidul village government also carries out its function of institutional development. Thus, the Pujonkidul government does not only carry out government functions by Hall, but also other functions, which is the finding of this study regarding the role of the government in the rural tourism development.

The successful case study of the Pujonkidul village government in developing rural tourism also confirms the thesis of Wilson et al. [15] that rural tourism development can be carried out without involving outsiders. The government functions in tourism development by Hall are government functions at the national and regional levels. However, the Pujonkidul village government carries out this function in the rural development process. This condition indicates that this function can be performed by the village government with its authority. The Pujonkidul village government has succeeded in constructing rural tourism autonomously through the BUMDes Sumber Sejahtera. In fact, formally the village government regulates that tourism development in the village can only be conducted by the government through BUMDes, village residents and/or community cooperation with the government. Thus, the authority of the village government can independently develop rural tourism by maximizing the potential of the village without having to involve outside actors and investment.

The results of this study have contributed to the addition of government functions in the tourism development process, namely institutional development. This case study found a new function of government in tourism development in addition to the functions introduced by Michael Hall. If Hall introduces eight functions of government in tourism development (two of which we combine following Mill \& Morrison [44], namely stimulation and promotion), this study finds one additional function. Thus, we argue that in tourism development the government can carry out the functions of co-ordination, planning, legislation and regulation, entrepreneurship, stimulation and promotion, a social tourism role, a broader role of interest protection, and institutional development.

Although this research discusses the role of village government in rural tourism development, this study ignored the discussion of local participation, which is also considered an essential form of rural tourism development by Wilson et al. [15]. This is a limitation of this study that needs to be discussed in future studies. Thus, the two prerequisites proposed in Wilson et al. can be addressed more comprehensively. However, this research has shown that village governments in Indonesia can maximize the role of the government in rural tourism development with their autonomous authority. This model can be adopted and developed in the other villages in Indonesia, particularly and around the world in general.

\section{ACKNOWLEDGMENTS}

The authors would like to thank the Indonesia Endowment Fund for Education (Lembaga Pengelola Dana Pendidikan/ LPDP), Ministry of Finance of the Republic of Indonesia for providing financial support for the research on which this article is based.

\section{REFERENCES}

[1] Su, L.J., Huang, S.S., Huang, J. (2018). Effects of destination social responsibility and tourism impacts on residents' support for tourism and perceived quality of life. Journal of Hospitality and Tourism Research, 42(7): 1039-1057. https://doi.org/10.1177/1096348016671395

[2] Ming, M., Wall, G., Wang, Y., Jin, M. (2019). Livelihood sustainability in a rural tourism destination Hetu town, Anhui. Tourism Management Journal, 71: 272-281. https://doi.org/10.1016/j.tourman.2018.10.019

[3] Andereck, K.L., Nyaupane, G.P. (2011). Exploring the nature of tourism and quality of life perceptions among residents. Journal of Travel Research, 50(3): 248-260. https://doi.org/10.1177/0047287510362918 
[4] Utomo, S.H., Wulandari, D., Narmaditya, B.S., Ishak, S., Prayitno, P.H., Sahid, S., Qodri, L.A. (2019). Ruralbased tourism and local economic development: Evidence from Indonesia. GeoJournal of Tourism and Geosites, 31(3):

$1161-1165$

https://doi.org/10.30892/gtg.31330-553

[5] Wang, L., Yotsumoto, Y. (2019). Conflict in tourism development in rural China. Tourism Management, 70: 188-200. https://doi.org/10.1016/j.tourman.2018.08.012

[6] McLennan, C.J., Ritchie, B.W., Ruhanen, L.M., Moyle, B.D. (2014). An institutional assessment of three local government-level tourism destinations at different stages of the transformation process. Tourism Management, 41: 107-118. https://doi.org/10.1016/j.tourman.2013.09.007

[7] Park, J.H., Lee, C., Yoo, C., Nam, Y. (2016). An analysis of the utilization of Facebook by local Korean governments for tourism development and the network of smart tourism ecosystem. International Journal of Information Management, 36(6): 1320-1327. https://doi.org/10.1016/j.ijinfomgt.2016.05.027

[8] Koopmans, M.E., Rogge, E., Mettepenningen, E., Knickel, K., Sümane, S. (2018). The role of multi-actor governance in aligning farm modernization and sustainable rural development. Journal of Rural Studies, 59: 252-262.

https://doi.org/10.1016/j.jrurstud.2017.03.012

[9] Liu, C., Dou, X., Li, J., Cai, L.A. (2020). Analyzing government role in rural tourism development: An empirical investigation from China. Journal of Rural Studies, $\quad 79$ : 177-188. https://doi.org/10.1016/j.jrurstud.2020.08.046

[10] Amerta, I.M.S. (2017). The role of tourism stakeholders at Jasri tourism village development, Karangasem regency. International Journal of Social Sciences and Humanities, $1(2)$ : 20-28 https://doi.org/10.29332/ijssh.v1n2.32

[11] Luo, F., Moyle, B. D., Bao, J., Zhong, Y. (2016). The role of institutions in the production of space for tourism: National Forest Parks in China. Forest Policy and Economics, 70: 47-55. https://doi.org/10.1016/j.forpol.2016.05.021

[12] Ruhanen, L. (2013). Local government: Facilitator or inhibitor of sustainable tourism development? Journal of $\begin{array}{lll}\text { Sustainable } \quad \text { Tourism, } & \text { 21(1): }\end{array}$ https://doi.org/10.1080/09669582.2012.680463

[13] Situmorang, R., Trilaksono, T., Japutra, A. (2019). Friend or foe? The complex relationship between indigenous people and policymakers regarding rural tourism in Indonesia. Journal of Hospitality and Tourism Management, 39: 20-29. https://doi.org/10.1016/j.jhtm.2019.02.001

[14] Dahles, H. (1998). Tourism, government policy, and petty entrepreneurs in Indonesia. South East Asia Research, 6(1): 73-98.

[15] Wilson, S., Fesenmaier, D.R., Fesenmaier, J., Van Es, J.C. (2001). Factors for success in rural tourism development. Journal of Travel Research, 40(2): 132-138. https://doi.org/10.1177/004728750104000203

[16] Kodir, A., Ahmad, R., Meiji, N.H.P. (2020). The dynamics access on tourism governance in Wakatobi national park. GeoJournal of Tourism and Geosites, 32(4): 1376-1383. https://doi.org/10.30892/gtg.32427583

[17] Putri, A.E., Khadijah, U.L.S., Novianti, E. (2020).
Community empowerment in the development of mangrove tourism in Batu Karas of Pangandaran, West Java. Geojournal of Tourism and Geosites, 31(3): 972978. https://doi.org/10.30892/gtg.31306-529

[18] Sumarmi, Kurniawati, E., Aliman, M. (2020). Community based tourism (CBT) to establish blue economy and improve public welfare for fishing tourism development in Klatak Beach, Tulungagung, Indonesia. Geojournal of Tourism and Geosites, 31(3): 979-986. https://doi.org/10.30892/gtg.31307-530

[19] Atmoko, T.P.H. (2014). Strategi Pengembangan Potensi Desa Wisata Brajan, Kabupaten Sleman. Jurnal Media Wisata, 12(2): 146-154.

[20] Nalayani, N.N.A.H. (2016). Evaluasi dan Strategi Pengembangan Desa Wisata Di Kabupaten Badung, Bali. JUMPA: Jurnal Master Pariwisata, 2(2): 189-198.

[21] Attar, M., Hakim, L., Yanuwiadi, B. (2013). Analisis Potensi dan Arahan Strategi Kebijakan Pengembangan Desa Ekowisata Di Kecamatan Bumiaji - Kota Batu. Journal of Indonesian Tourism and Development Studies, 1(2): 68-78.

[22] Hermawan, H. (2016). Dampak pengembangan desa wisata nglanggeran terhadap sosial budaya masyarakat lokal. Seminar Nasional Ilmu Pengetahuan Dan Teknologi Komputer (SNIPTek) Nusa Mandiri, 60-70. Jakarta: STMIK Nusa Mandiri.

[23] Satria, D. (2009). Strategi Pengembangan Ekowisata Berbasis Ekonomi Lokal Dalam Rangka Program Pengentasan Kemiskinan di Wilayah Kabupaten Malang. Journal of Indonesian Applied Economics, 3(1): 37-47.

[24] Sudarmadji, D.D. (2014). Dampak Lingkungan dan Risiko Bencana Pengembangan Desa Wisata; Studi Kasus di Desa Wisata Sambi. Kawistara, 4(2): 111-224.

[25] BPS. (2018). Hasil Pendataan Potensi Desa (Podes) 2018. Berita Resmi Statistik No. 99/12/Th.XXI, Desember 2018, pp. 1-12.

[26] WTO. (2018). UNWTO Tourism Highlights, 2018 Edition. Madrid. https://doi.org/10.18111/9789284419876

[27] Wang, X., Wang, X., Wu, J., Zhao, G. (2017). Social network analysis of actors in rural development: A case study of Yanhe Village, Hubei Province, China. Growth and Change, 48(4): 869-882. https://doi.org/10.1111/grow.12195

[28] Ezeuduji, I.O. (2017). Change management for subSaharan Africa's rural tourism development. Current Issues in Tourism, 20(9): 946-959. https://doi.org/10.1080/13683500.2014.946892

[29] Pelales, R.M.Y. (2002). Rural tourism in Spain. Annals of Tourism Research, 29(4): 1101-1110. https://doi.org//10.1016/S0160-7383(02)00025-7

[30] Tolstad, H.K. (2014). Development of rural-tourism experiences through networking: An example from Gudbrandsdalen, Norway. Norwegian Journal of Geography, 68(2): 111-120. https://doi.org/10.1080/00291951.2014.894561

[31] Fagertun, A. (2017). Labour in Paradise: Gender, class and social mobility in the informal tourism economy of Urban Bali, Indonesia. The Journal of Development Studies, 53(3): 331-345. https://doi.org/10.1080/00220388.2016.1184248

[32] Nair, V., Munikrishnan, U.T., Rajaratnam, S.D., King, N. (2015). Redefining rural tourism in Malaysia: A conceptual perspective. Asia Pacific Journal of Tourism 
Research, 20(3):

314-337.

https://doi.org/10.1080/10941665.2014.889026

[33] Lane, B. (1994). What is rural tourism? Journal of Sustainable Tourism, 2(1-2): 7-21. https://doi.org/10.1080/09669589409510680

[34] Ghaderi, Z., Henderson, J.C. (2012). Sustainable rural tourism in Iran: A perspective from Hawraman Village. Tourism Management Perspectives, 2-3: 47-54. https://doi.org/10.1016/j.tmp.2012.03.001

[35] Lane, B., Kastenholz, E. (2015). Rural tourism: The evolution of practice and research approaches - Towards a new generation concept? Journal of Sustainable Tourism, 23(8-9):

1133-1156 https://doi.org/10.1080/09669582.2015.1083997

[36] Pesonen, J., Komppula, R., Kronenberg, C., Peters, M. (2011). Understanding the relationship between push and pull motivations in rural tourism. Tourism Review, 66(3): 32-49. https://doi.org/10.1108/16605371111175311

[37] Siemens, L. (2007). Challenges faced by rural/remote tourism businesses on Vancouver Island: An exploratory study. Journal of Enterprising Communities: People and Places in the Global Economy, 1(4): 308-320. https://doi.org/10.1108/17506200710833818

[38] Clarke, J., Denman, R., Hickman, G., Slovak, J. (2001). Rural tourism in Roznava Okres: A Slovak case study. Tourism Management, 22(2): 193-202. https://doi.org/10.1016/S0261-5177(00)00038-8

[39] Pakurar, M., Olah, J. (2008). Definition of rural tourism and its characteristics in the northern great plain region. Analele Universitatii Din Oradea, Fascicula: Ecotoxicologie, Zootehnie Si Tehnologii de Industrie Alimentara, 7(7): 777-782.

[40] Nunkoo, R., Ramkisson, H. (2011). Developing a community support model for tourism. Annals of Tourism Research, 38(3): 964-988. https://doi.org/10.1016/j.annals.2011.01.017

[41] Devine, A., Devine, F. (2011). Planning and developing tourism within a public sector quagmire: Lessons from and for small countries. Tourism Management, 32(6):
1253-1261.

https://doi.org/10.1016/j.tourman.2010.11.004

[42] Wang, C., Xu, H. (2011). Government intervention in investment by Chinese listed companies that have diversified into tourism. Tourism Management, 32(6): 1371-1380. https://doi.org/10.1016/j.tourman.2011.01.012

[43] Hall, C.M. (2005). The role of government in the management of tourism: The public sector and tourism policies. In L. Pender \& R. Sharpley (Eds.), The Management of Tourism, 2018-2231. London: SAGE Publications https://doi.org/10.4135/9781446214961.n15

[44] Mill, R.C., Morrison, A.M. (1985). The Tourism System: An Introductory Text. Englewood Cliffs: Prentice-Hall International.

[45] McGill, R. (1996). Institutional Development; A Third World City Management Perspective. London: Macmillan Press LTD.

[46] Buyck, B. (1991). The Bank's Use of Technical Assistance for Institutional Development (No. 578). http://documents.worldbank.org/curated/en/9234014687 64402328/pdf/multi-page.pdf.

[47] Cresswell. (1998). Research Design: Qualitative \& Quantitative Approaches. Thousand Oaks, California: Sage Publications.

[48] Yin, R.K. (2003). Case Study Research; Design and Methods (Third Edit). London: Sage Publication Ltd.

[49] Eden, C. (2004). Analyzing cognitive maps to help structure issues or problems. European Journal of Operational Research, 159(3): 673-686. https://doi.org/10.1016/S0377-2217(03)00431-4

[50] Miles, M.B., Huberman, A.M. (1992). Analisis Data Kualitatif: Buku Sumber Tentang Metode-Metode Baru. Jakarta. UI Press.

[51] Beckert, J. (2010). Institutional isomorphism revisited: Convergence and divergence in institutional change. Sociological Theory, 28(2): 150-166. https://doi.org/10.1111/j.1467-9558.2010.01369.x 